\title{
Mark Peterson, Sustainable Enterprise: A Macromarketing Approach (2013)
}

Canan Madran

Dokuz Eylül University

Follow this and additional works at: https://digitalcommons.uri.edu/mgdr

Part of the Anthropology Commons, Economics Commons, Marketing Commons, Other Business Commons, and the Sociology Commons

\section{Recommended Citation}

Madran, Canan (2017) "Mark Peterson, Sustainable Enterprise: A Macromarketing Approach (2013)," Markets, Globalization \& Development Review. Vol. 2: No. 4, Article 5.

DOI: 10.23860/MGDR-2017-02-04-05

Available at: https://digitalcommons.uri.edu/mgdr/vol2/iss4/5

This Book Review is brought to you for free and open access by DigitalCommons@URI. It has been accepted for inclusion in Markets, Globalization \& Development Review by an authorized editor of DigitalCommons@URI. For more information, please contact digitalcommons-group@uri.edu. 
Mark Peterson, Sustainable Enterprise: A Macromarketing Approach (2013)

\section{Markets, Globalization \& Development Review}
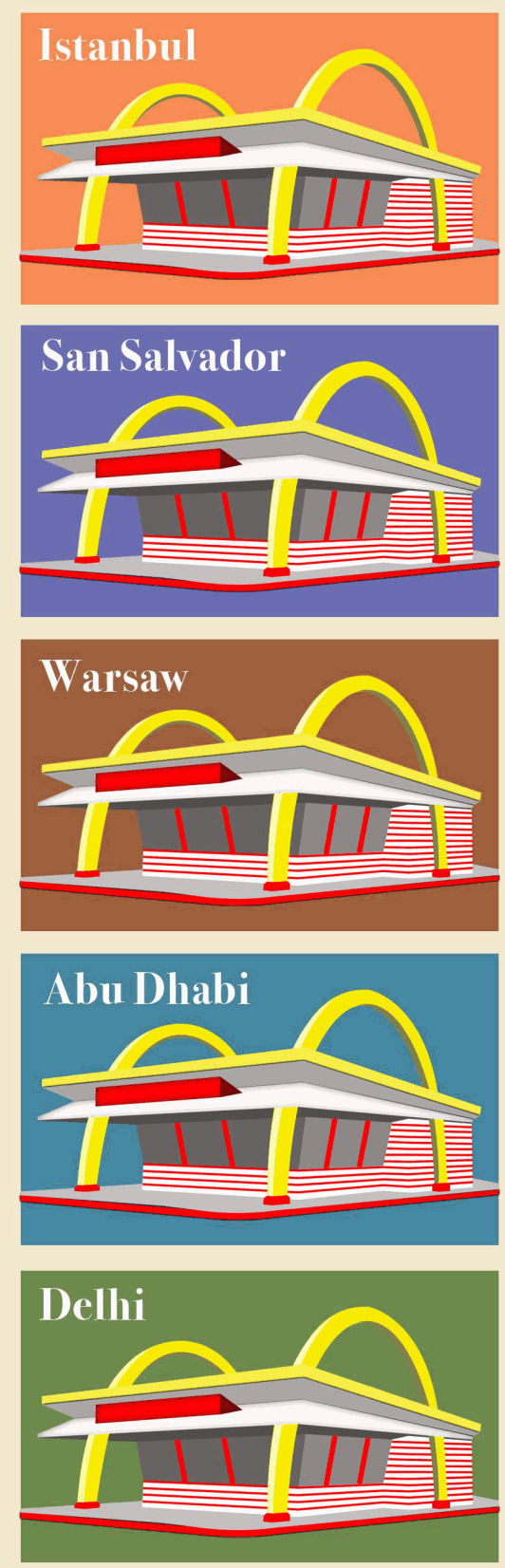
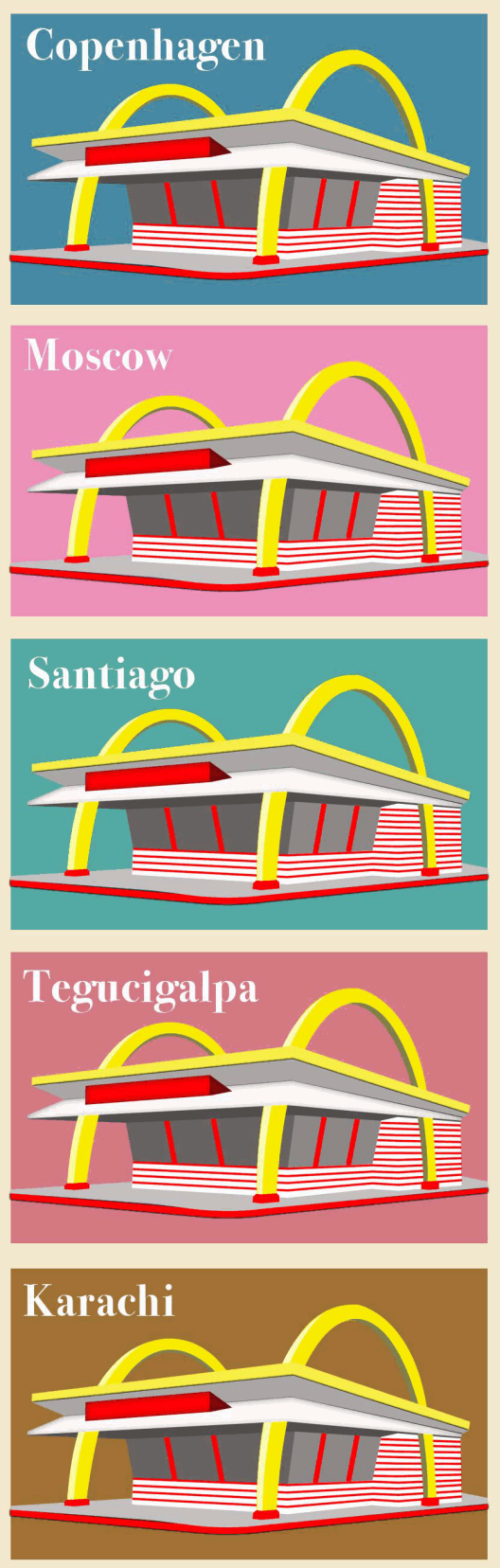
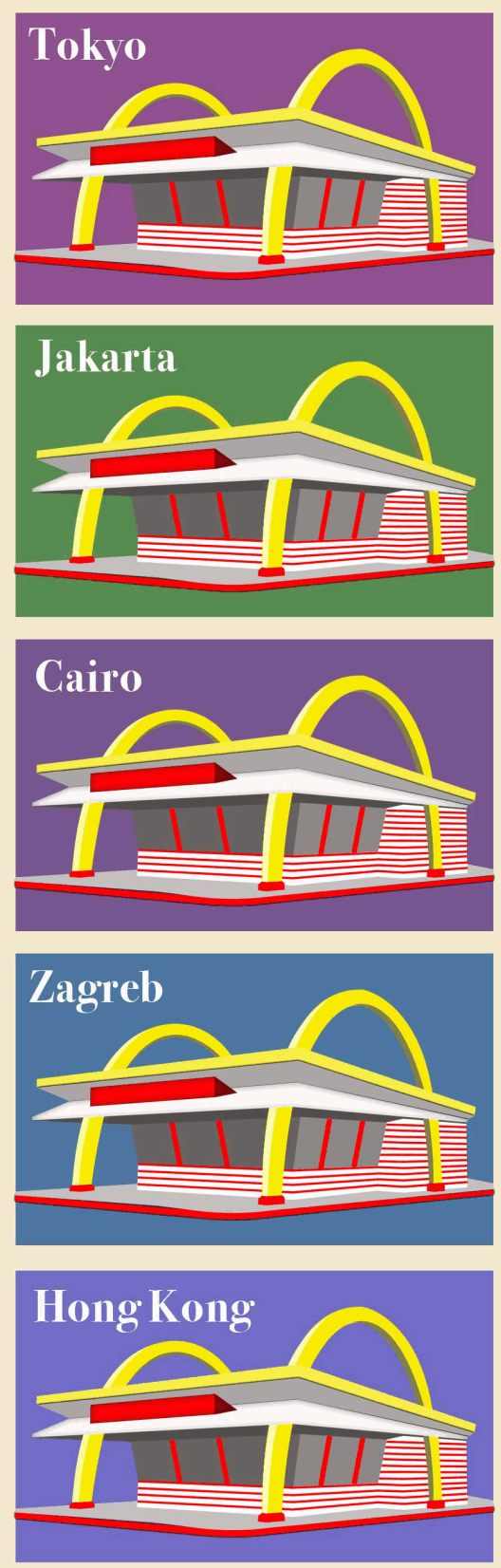

This book review is available in Markets, Globalization \& Development Review: https://digitalcommons.uri.edu/mgdr/ 
Book Review

\section{Mark Peterson, Sustainable Enterprise: A Macromarketing Approach (2013)}

\section{Introduction}

In this book, with a comprehensive sweep of sustainability issues, Mark Peterson (2013) provides a holistic approach for businesses in the marketplace, laying out solutions about how they can operate with a social conscience and make profit at the same time. Entitled Sustainable Enterprise: A Macromarketing Approach, this 2013 book makes a contribution to the sustainability discourse in general, and a particularly strong contribution in the field of marketing - a field where sustainability topics are moving into the foreground (see, e.g., Kumar and Dholakia 2016). In the introduction to the book, Mark Peterson - a professor at the University of Wyoming - invites businesspersons to tap into the wisdom accrued in macromarketing scholarship over three decades. I believe Peterson's insightful and invaluable work also contributes to the call of MGDR editors on "how to make the world better, cleaner, safer, peaceful, provident, tolerant, harmonious and fairer" (Dholakia and Atik 2016, p. 7).

Mark Peterson is also the editor of the Journal of Macromarketing, and he currently serves on the board of directors of the Macromarketing Society and the International Society for Quality of Life Studies (ISQOLS). His research has been published in wellrecognized journals such as the Journal of Macromarketing, Journal of Academy of Marketing Science, Journal of Public Policy \& Marketing, and more. Even with a quick look at his previous research on pressing societal issues such as quality of life, sustainability, and societal development, one can easily understand how Peterson's academic areas of interest and extensive research background give him the knowledge and perspective to produce this far-reaching book.

Peterson proposes his book for a variety of courses, including Marketing and Society, Business and Society, and Marketing Strategy, but he especially finds it suitable for Sustainable Enterprise, Sustainable Business, and Sustainable Marketing courses. Even though I completely agree with his suggestions, I think that this book can also be beneficial in providing a societal touch in generic marketing courses such as the Principles of Marketing, Marketing Management, and Global/International Marketing courses. The content in the book will make valuable additional inputs whenever and wherever environmental, social, and economic-financial issues are covered in such general courses, compared to the current textbooks that do not delve deeply into sustainability topics. 
The concept of sustainability has created the need for an intellectual and behavioral transformation in marketing (Kumar and Dholakia 2016) - in terms of understanding, practice, and the research literature. To name just the leading few, many macromarketing scholars have been studying interactions between markets, marketing, and society to increase quality of life, social welfare, and sustainability (e.g., Kilbourne et al. 1997; McDonagh and Prothero 1997; Özdamar Ertekin and Atik 2015; Shapiro et al. 2009). Many researchers (e.g., Grant 2010; Jackson 2005) suggest that the form of community organization must be transformed by a paradigm shift in order to solve the newly posed problems. As an extension of this approach, 'transformation for sustainability in marketing' - both for practitioners and academics - can also be interpreted as a new form of social organization.

Peterson suggests that the transition of businesses into this new paradigm should be through a vision that is built upon a triple-bottomline framework composed of environmental integrity, economic prosperity, and social justice. Starting with the physical structure (facilities and premises) of the business, pro-sustainability changes need to happen in the vision of the upper and middle management, technologies employed, the firm's community and relations with the stakeholders, the staff and of course the intermediate and the end customers.

In my view, Peterson has already accomplished his purpose of introducing the business professionals and marketing scholars interested in sustainability to the corpus of wisdom available in macromarketing. In his analysis, he took a historical perspective covering the modern marketing era and showing the successes and failures of the marketplace in relation to sustainability. Peterson's broad analysis of the problems and the remarkable content of the book make it unique.

By providing many corporate and entrepreneurial examples both in the "Vignettes" and "Mavericks" sections of the book, Peterson illustrates very clearly how businesses can benefit from taking a more holistic approach to their transition towards sustainability. For example, the Patagonia company case - which is explained in detail - tells a particularly remarkable story of such a holistic approach. Patagonia's mission statement, "Build the best product, cause no unnecessary harm, use business to inspire and implement solutions to the environmental crisis," and its former CEO, Casey Sheahan's statement, "there is no such thing as a sustainable company, we're just doing the best we can" (p. 347) capture both the company's and the book's perspective on sustainability.

Peterson also claims that the readers will find the book "refreshingly different" from the current books in marketing, and he is 
right about this as he had configured the content differently from the conventional books in the field. He devoted entire chapters to important societal concepts and views, which has usually been squeezed into a few sentences or paragraphs in most of the generic books in marketing.

\section{More on the content of the book}

To turn to the main parts of the book, Part 1 presents macromarketing as a valuable framework to develop a better understanding of the current happenings in marketplaces and explores the various stakeholders in marketing: mainly consumers, businesses and the state. It shows how the current economic system - led by self-interest and competition - has failed to keep the markets away from social and environmental disasters, and suggests that sustainable business practices will (eventually) be known simply as 'good business'. In Part 2, Peterson points at the importance of the telecommunications technology empowering individual consumers and citizens. Through Internet and the social media, the consumer-to-consumer, consumerto-business, and business-to-business relationships enable new consumption experiences such as collaborative consumption, and relearning how to create value out of shared and open resources in ways that balance personal self-interest and the interest of the larger community. According to the author, the sociopolitical forces today can change more rapidly as a result of activist citizens' ability to mobilize public opinion. In this part, Peterson also discusses the impact of globalization on marketplace and society.

Part 3 highlights the threats of excessive consumption and production imposed on the natural environment and explores the possibilities of less materialistic and less status-seeking consumption, accepting and learning to consume less, examining topics like green marketing and demarketing. Peterson presents demarketing, which has unfortunately been one of the relatively underrated concepts of $1980 \mathrm{~s}$ and 1990s, as a strong potential tool:

.... the solution offered by the critical school of macromarketing that calls for less consumption seems to be an important element in future approaches to doing business in a way that benefits the environment. In short, demarketing consumption will likely be a social marketing effort that will take a broad and enduring effort to make it cool to consume less in the future" (p. 365).

Part 4 continues to discuss the impact of globalization on developing markets, the advantages and disadvantages of capitalism, and possible solutions for poverty alleviation. 
Finally, Part 5 - taking an entrepreneurial perspective - explores the solutions to one of most thought-provoking contemporary challenges, i.e., how to make money and save the world at the same time. More specifically, this part shows how - by pursuing marketbased sustainability in business - more and more firms succeed in creating social value, as well as financial value for the company. The author points at the need of the combined effort from businesses, government, and nongovernmental organizations (NGOs) that could be effective in alleviating some of the pressing problems of the world.

As said earlier, Peterson's book has already claimed a special place in sustainability business and sustainability marketing literature with its holistic and multidisciplinary approach - covering historical, philosophical, technological, societal perspectives; and more. The historical and biographical tone of the book emphasizes the significance of the sustainable enterprise, which makes the book even more valuable.

Each chapter begins with critical introductory cases that are a bit lengthier than the ordinary. Surprisingly, different stories that the author gathers from all around the world fit into the chapters well, making them easier and more exciting to read. The author supports the reader with lots of clues to better understand the "To Whom Does a Business Person Owe Allegiance?" dilemma of politics and business.

The "Your Thoughts?" part related to each introductory case invites the readers to engage with the context and be involved practically and philosophically with the cases provided. For example, the Max Keith-Coca Cola case helps readers to think about the question and elaborate on their thoughts on "how to behave as a company manager" even in the turbulent times of the brutal war environment under Nazi Government in Germany in the 1939-45 period. Coca Cola label, which is regularly attacked and insulted as a global imperialist in anti-globalization discussions, makes the case even more thought-provoking. Virtually any reader can find an example related to their areas of interest easily within the book because it provides a very wide range of examples and evidence from various disciplines such as history, economics, politics, music, sociology, technology, and business.

After providing the reader with some food for thought, in the "Chapter Overview and Learning Objectives" part of each chapter there are some detailed introductory paragraphs followed by questions to be answered in order to achieve the desired learning objectives. Readers find a detailed, long (but far from redundant or dull) discussion on the topic of each chapter. The author uses large paragraphs involving deep theoretical discussions while staying concise and interesting.

"Mavericks Who Made It" parts are especially interesting because point to the idea of "a new paradigm shift" in doing business 
and marketing, by bringing forth the examples of risk-takers from various areas under the spotlight.

At the end, contact information (in parts Supplier Profile or Important Notes) related to the case is provided in the boxes. This particular implication directs the reader's interest towards the profile of do-gooders.

Finally, the questions at the end of each chapter facilitate the reader's overview of the most important concepts and theories of the chapter, directing the reader's attention once again to the crucial details, yet keeping the discussion open-ended.

\section{Conclusion}

Peterson's book takes a macromarketing approach. Various socioeconomic, historical, sociological, political, and environmental examples and relevant issues are tackled in detail around a macromarketing framework.

As a textbook, I would recommend it for all kinds of business and marketing courses, including generic marketing courses, global/international marketing courses, courses related to sustainability, sustainable production and sustainable consumption.

Taking a critical perspective on sustainability, Peterson's book opens up a new page in textbook writing in marketing. The motivation of this book is more "societal wellbeing" oriented, which is different than most other books in the field of marketing that are generally "firm/brand" oriented. 


\section{References}

Dholakia, Nikhilesh and Deniz Atik (2016), "Markets, Globalization, Development: Charting the Intersections of Tree Multipolar Concepts," Markets, Globalization \& Development Review, 1 (1), Article 1. https://doi.org/10.23860/MGDR-2016-01-01-01

Grant, John (2010), Co-opportunity: Join Up for a Sustainable, Resilient, Prosperous World-Hardcover - March 15, John Wiley \& Sons, UK.

Jackson, Tim (2005), Motivating Sustainable Consumption a Review Of Evidence on Consumer Behaviour And Behavioural Change, $A$ report to the Sustainable Development Research Network, Centre for Environmental Strategy, University of Surrey, GUILDFORD Surrey, [available at http://www.sustainablelifestyles.ac.uk/sites/default/files/motivatin g sc final.pdf].

Kilbourne, William, Pierre McDonagh and Andrea Prothero (1997), "Sustainable Consumption and the quality of life: A macromarketing challenge to the dominant social paradigm," Journal of Macromarketing, 17 (1), 4-24. https://doi.org/10.1177/027614679701700103

Kumar, Bipul and Nikhilesh Dholakia (2016), "Toward Pro-Sustainability Actions: A Macro-Behavioral Perspective", Review of Marketing Research, 13, 169-92. https://doi.org/10.1108/s1548$\underline{643520160000013015}$

McDonagh, Pierre and Andrea Prothero (1997), Green management: A reader. International Thomson Business Press.

Özdamar Ertekin, Zeynep and Deniz Atik (2015), "Sustainable Markets: Motivating Factors, Barriers, and Remedies for Mobilization of Slow Fashion," Journal of Macromarketing, March 35, 53-69. https://doi.org/10.1177/0276146714535932

Peterson, Mark (2013), Sustainable Enterprise: A Macromarketing Approach. New York: Sage

Shapiro, Stanley J., Mark Tadajewski and Clifford J. Schultz (2009), "Interpreting Macromarketing: The Construction of a Major Macromarketing Collection," Journal of Macromarketing, 29 (3), 325-34. https://doi.org/10.1177/0276146709338706 